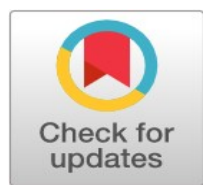

\title{
Financial literacy and SMEs' potential entrepreneurs: The case of Malaysia
}

\author{
Noraizan Ripain ${ }^{1 *}$, Sharifah Milda Amirul ${ }^{2}$, Rasid Mail ${ }^{3}$ \\ 1, 2, 3 Faculty of Business, Economics and Accountancy, Universiti Malaysia Sabah, Kota Kinabalu, Malaysia
}

\author{
Index Terms \\ Financial literacy \\ Decision making \\ Entrepreneur \\ SME's
}

Received: 25 December 2016

Accepted: 4 February 2017

Published: 21 April 2017

\begin{abstract}
Malaysia, like many other countries, is depending on Small and Medium Enterprises (SMEs) activities in generating national income, creating job opportunities and tapping local and overseas market. As such country like Malaysia is putting a great effort to nurture entrepreneurs to become SME players by providing infrastructure, financial assistance, skills, training and conducive ecosystem for entrepreneurial development. One of the important aspects to address is the ability of the entrepreneurs to manage financial matters effectively. The ability, so called financial literacy, is important for the survival of the enterprise, as acknowledged by many. Practitioners and researchers have proved the significance of financial literacy in determining the success and failure of enterprise management, particularly among young entrepreneurs. As such it is important to understand and investigate the level of financial literacy among entrepreneurs. This paper is presenting a case to investigate the level of financial literacy among the participants of an entrepreneur development program, organised by a State in Malaysia, through a special program entrusted to an implementing agency. The objective of the program is to nurture potential entrepreneurs to develop the development corridor gazetted by the Federal Government in the State. Since the success of this program is critical to the overall objective of the gazetted development corridor this paper intends to investigate the level of financial literacy among the participants, as the main objective of the case. Accordingly, the next objective is to enlighten the importance of enhancing financial literacy so as to provide input to the policy makers and implementing agencies in relevant projects. By employing quantitative approach through questionnaire survey and interview, this paper found that the level of financial literacy among SMEs' players, particularly those selected to be nurtured as new entrepreneurs is still alarming (Chamwada, 2015). As such this paper advocates the importance of education in financial management among selected participants of entrepreneurial development program as well as formulating a sound monitoring system as part of a good ecosystem in nurturing entrepreneurs to become SME players. Finally the finding of this paper offers an insight evidence to strengthen financial literacy theory, therefore, this paper makes some suggestion regarding the potential coverage of a more comprehensive future study.
\end{abstract}

(C) 2017 The Author(s). Published by TAF Publishing.

\section{INTRODUCTION}

The economic and social roles played by (SMEs) in Malaysia have been acknowledged. Ranging from providing job opportunities to contributing significantly to the national GDP, the history of SME has been highlighted overwhelmingly for years (Hoq, Che Ha \& Said, 2009). Indeed its instrumental roles since 1960s towards the nation building of Malaysia have been exemplary to other countries (Gunto \& Alias, 2013) and are expected to be more crucial in contributing towards Malaysia's GDP in the years to come (Koe, Omar \& Sa'ari, 2015). This is made sensible by looking into the fact that $97.3 \%$ of current business establishment in Malaysia consists of SMEs that provide about $52.7 \%$ of total employment in the country (Salikin, Ab Wahab \& Muhammad,

\footnotetext{
${ }^{*}$ Corresponding author: Noraizan Ripain

†Email: noraizan@ums.edu.my
} 
2014). Since SMEs contribute significantly to economic development of many countries, the performance and growth of SMEs become a great concern for various parties such as government, policy makers, financial institutions, among others. One of the most common highlighted success factors of SME is the aspect of financial management (Salikin et al., 2014) particularly among those operating in developing countries (Wang, 2016). In a more specific manner Hoe (2010) suggested that the issues of financial management among SMEs consist of six components; financial planning and control, financial accounting, financial analysis, management accounting, capital budgeting and working capital management.

The issues of financial management faced by SMEs all over the world are obviously related to the capability of their managers (Mazzarol, 2014). In many occasions, they are the owners of the enterprises. Indeed many aspects of SMEs' management process are related to financial management, as early as at the financing decision, operational control, performance management, and future planning. In its technical term, these managerial capabilities are referred to as financial literacy. Financial literacy is the term used to imply the capability of managers to manage money effectively and efficiently in financial decision making processes (Marcolin \& Abraham, 2006). The significance of financial literacy among SMEs' managers in ensuring the survival of their enterprises, particularly in harnessing the contemporary and future challenges has been advocated widely (Ankunda, 2010). As such practitioners and researchers in the area of SME proclaim the importance of addressing the gap in financial literacy among SME entrepreneurs, particularly through proper and adequate financial education (Lennox, 2014).

Hence some scholars advocate that financial illiteracy is the worst enemy for SMEs (Shafique et al., 2016) while others attributed it to the failure of SMEs all over the world (Wise, 2013).Taking into account the importance of financial literacy among SMEs' managers, this paper is reporting the result of an empirical investigation on the level of financial literacy among selected participants in a special entrepreneurial nurturing program organised by the state government in Malaysia. Its main objective is to investigate the level of financial literacy among the participants. As such the findings could benefit the related parties, in particular the implementing agencies, other researchers and the target group. The paper is organized as follows: The next section introduces the background of study. Section 3 includes an overview of related literature and provides a critical discussion on findings with respect to SMEs and financial literacy. Section 4 presents the research design, sample and data collection used in this research. Meanwhile, section 5 outlines and discusses the results and section 6 presents the concluding remarks of the study.

\section{Background of the Study}

This study is grounded among the participants of entrepreneur nurturing program organised by a state government agency in one of the states in Malaysia (identified as the State thereafter). The agency, hereafter identified as XYZ, is the government machinery responsible to nurture entrepreneurs through related entrepreneurship programs that are planned throughout the year. XYZ was established in 2008 with the mission to enhance the quality of life of the people by accelerating the growth of the State's economy, promoting regional balance and bridging the rural-urban divide while ensuring sustainable management of the State's resources. Its establishment was in line with the launching of the State's development corridor. In due course the State's administrative area has been clustered into a number of development corridors with the aim to optimise economic resources and unique demographical attributes of each cluster. In that effort the creation of entrepreneurship programs and nurturing of potential entrepreneurs are among the main agendas.

The respondents of this study are the participants of one of the entrepreneurship development programs organised by XYZ as a mean to enhance SME activities in the said economic development corridor. The said program is identified as 'Gerak IKS SDC 2016' where a group of potential entrepreneurs is selected, trained, provided with financial and physical support, monitored and nurtured to be a SME player. For the purpose of this study, the definition of SMEs applied by Malaysian National Bank (BNM) is adopted. BNM defines SMEs based on two sectors; (i) manufacturing and (ii) services and other sectors. These two sectors are distinguished based on the number of full time employees and the amount of sales turnover. Manufacturing sector with the number of employees not exceeding 200 workers and the sales turnover not exceeding RM50 million is considered SME. Meanwhile for services and other sectors, to be qualified as SME, the number of employees should not exceed 75 and the sales turnover should not exceed RM20 million. A business will be deemed as an SME if it meets either one of the two specified criteria, namely sales turnover or full-time employees whichever is lower . XYZ is entrusted as a one-stop centre for the whole state 
to promote and accelerate the development of the state development corridor that provides related services to investment activities. For that purpose, the State's Legislative Assembly initiated the establishment of XYZ via its own authoritative enactment in January 2009. The enactment was officially assented by The Head of the State on 23 February 2009 and accordingly gazetted on 26 February the same year. Among others, the function of XYZ is to promote entrepreneurial activities among SMEs' players. Following the launching of the abovementioned development corridor, an initial development budget was approved for implementation under the State's development corridor SDC via the Mid-Term Review of the Ninth Malaysia Plan.

The Federal Government channels development allocation to the State government through XYZ, to finance development project in the corridor. XYZ serves two main objectives namely, to promote and accelerate the development of the corridor area into a leading economic region and a choice destination for investment, work and living. It is to ensure that social development and sustainable development are kept as priorities whilst driving economic growth in the corridor development area. In addition, some of the XYZ's functions are to recommend to the Federal Government any potential projects to be implemented for the economic growth and opportunities in the corridor development area.

As such $\mathrm{XYZ}$ is responsible to disburse funds received from the Government or the Federal Government for the corridor development area to the relevant implementing agencies. In this effort, XYZ coordinates the expeditious implementation of all projects in the corridor development area by performing the functions of a one-stop centre. Subsequently $\mathrm{XYZ}$ is responsible for monitoring and reporting to the State and the Federal Government the progression status of all projects in the corridor development area.

\section{Entrepreneur Program of XYZ}

One of the main responsibilities of XYZ is to develop and regulate entrepreneurial program in the State. Indeed, this is in line with the effort to enhance SMEs' development in the State which was further accelerated by the State decision to intensify economic development via the subdivision of its administrative area into a number of development corridors. The subdivision was strategically decided by identifying each corridor's competitive advantage in terms of economic resources, human resources and other environmental factors. The 'Gerak IKS SDC 2016' is particularly created to foster the culture of entrepreneurship among $\mathrm{Bu}$ - miputera entrepreneurs in the State. XYZ, through its dedicated programs, is to equip the participants with knowledge and experience. The participants are exposed to the SME environment by providing opportunities to interact with established SMEs' players. Through the interaction, the participants are to discuss issues and challenges they encountered in managing their enterprise (Mgijima \& Flowerday, 2012). In due course, the established SMEs' players are sharing their experience, responding to the question posed by the participants, providing useful inputs and information and providing networking. The issues of financial management, vis-à-vis financial literacy is one of the most frequent issues highlighted during the interaction.

The 'Gerak IKS SDC 2016' is also to serve as a platform to help the participants to identify appropriate agencies, potential business area and develop networking. The program is jointly organised by XYZ, The Government's Bumiputra Agenda Steering Unit (TERAJU), SME Corporation (SME Corp), and other Malaysian government agencies. The participants have to attend a series of pre-determined periodical programs set by XYZ through 'Gerak IKS SDC 2016' program. This program is comprised of talks covering various industry opportunities and business assistance topics, as well as a mini exhibition to display the products of entrepreneurs of SMEs. As mentioned earlier, it is observed along the study that the issues of financial management and financial literacy were among the most highlighted areas during the talks, dialogue and interaction between and among the participants and established SMEs' players who got involved during the programs.

\section{LITERAT URE REVIEW}

World Bank (2012) and the Organisation for Economic Cooperation and Development (2011) define financial literacy as a combination of the awareness, knowledge, skills, attitudes and behaviours necessary to make sound financial decisions and ultimately achieve individual financial wellbeing. In addition, Marriott \& Mellett (1996) define financial literacy as the manager's ability to understand and analyze financial information and act accordingly (Olatunji, 2015). In general, financial literacy refers to one's ability to handle financial matters while in a more official manner, it implies the ability of business managers to make sound financial decision, execution and control. Concern about the level of financial literacy among entrepreneurs has started to gain more attention from many researchers lately. Their studies are focusing mainly on the investigation on the level of financial literacy among SMEs' entrepreneurs and its re- 
lationship or impact on SMEs' performance. Besides that, the importance and restraint of financial literacy among the entrepreneurs towards the success of their SMEs are also discussed in those studies. As an example, Plakaloviæ (2015) reported that owners of surveyed SMEs are financially illiterate and in certain aspects financially unaware. Based on the hypothesis that the owners of SMEs are financially illiterate or having a minimum level of financial literacy, this study discovered that the managers of SMEs involved in the survey and interviews were having unexpectedly low level of basic financial knowledge. To the worst, this study found that the awareness among those managers on the importance of financial literacy was disappointingly low.

In a comparable study by Fatoki (2014), the level of financial literacy among the owners of new microenterprises was also low. Comparatively Nunoo \& Francis (2012) in their studies found that there is moderate level of financial literacy among small and medium entrepreneurs. Consequently they discover that SMEs' entrepreneurs who have adequate financial literacy are more likely to utilize financial service such as operating a bank account. In the same vein, Kojo Oseifuah (2010) found that young entrepreneurs involved in the survey have financial literacy level above average, therefore, significantly contribute to their managerial skills and apparently are able to manage their enterprise better as compared to those having below average financial literacy.

Comparatively study done by Abubakar (2015) in Africa reported that those entrepreneurs who are having considerable level of financial literacy are having better capacity to deal with the issues of market accessibility, policy constraints and cultural barrier. This notion is supported by Cherugong (2015) who found that the level of financial literacy among managers is positively associated with a number of performance indicators such as the survival of enterprise (number of years in operation), number of employees, and annual growth of more than ten per cent. In a more rigorous study, Njoroge (2013) investigated randomly the successful and failed small enterprises in Kenya and found out interestingly that their success rate is significantly and positively associated with the level of financial literacy among the managers.

This relationship could be further explained by Bayrakdaroğlu \& Şan (2014) who found that financial literacy would enable SMEs' managers to optimise financial market instruments, as such having a greater capacity to expand their business. This notion was further validated and shared by Wise (2013) who found that financial literacy has enabled managers to adopt more useful financial tools, demonstrate better skills in generating and analysing financial reports, and more interestingly have a better probability of repaying business loan and consequently minimizing the risk of bankruptcy and business failure. According to Adomako \& Danso (2014), this is particularly critical when the resources are scarce and its market structure is flexible. In another insightful research among a number of small firms, Mutegi, Njeru \& Ongesa (2015) found that owners who are financially literate tend to use and analyse financial report prepared for them, and work on the information in order to make decision related to their firm. On the other hand, they found that owners who are financially illiterate tend to disregard the financial statement prepared for their firms, just compiling the statements in the filing system and rarely using in decision making process. This would unfavourably influence their ability to compete among SMEs. Halabi, Barrett \& Dyt (2010) in a comparable study on the type of financial information and its usage by the owners of a number of small firms, found that many of them limit the use of financial statement prepared for them to the purpose of tax calculation and tax return instead of using it strategically in decision making process.

In relation to this Tuyisenge, Mugambi \& Kemirembe (2015) discovered that the most common yet critical areas whereby financially illiterate managers used to encounter problems are in book keeping, credit management, and budgeting. In discussing this issue, Mutua (2015) insisted that accurate records of business transactions are necessary for the success of SMEs. However, his study discloses that those SMEs do not keep complete accounting records because their managers are financially illiterate and to the worst, it is quite costly to hire professional accountants. There are plenty of studies advocating the benefits of having an adequate financial education among entrepreneurs, as a mean to ensure the performance of their enterprises, particularly for those involved in SME (Kotzé \& Smit, 2008). As such writers such as Fernandes (2015) and Njoroge (2013) are quite persistent in their argument about the importance of education in financial management among entrepreneurs. As such this paper intends to investigate the level of financial literacy among the selected participants of 'Gerak IKS SDC 2016'.

It is hoped that the finding of this study not only contributes to the literature and body of knowledge, but more importantly can be used by the related agencies to tackle financial literacy issues in the existing and future en- 
trepreneurial programs they formulate and implement.

\section{RESEARCH METHODOLOGY}

The present study empirically analyses the level of financial literacy among the candidates of SMEs' entrepreneur program which is organized by the case agency, XYZ. The main theme of the study is highlighting the importance of financial literacy among the participants of an entrepreneurship program Gerak IKS SDC 2016 that is organised by the State through its implementing agency (XYZ) to enhance SME activities in the development corridor of the State.

\section{Research Design}

The research design of this study is based on quantitative method. To analyze the level of financial literacy among the candidates, this study uses a set of questionnaires designed by Lim, Osman, Zatul Karamah, Abd Jamal \& Awang Mohidin (2012). In designing the questionnaire, the authors adopt the ANZ Framework which divides the key skills and areas of knowledge into four categories namely (i) Mathematical Literacy and Standard Literacy, (ii) Financial Understanding. (iii) Financial Competence, and (iv) Financial Responsibility. However, to suit to the nature of study involving those participants who do not have high education background, the density of adopted questionnaire of Lim et al., (2012) was amended as to enable the participants to respond reliably. As such the employed questionnaire consists of only 27 questions in which 16 of them are related to financial literacy questions. The rest of the questions capture demographic variables. The 16 financial literacy question items are presented in multiple choice form of questions.

\section{Sample and Data Collection}

The sample of respondents in this study represents the candidates of SMEs' entrepreneur program, i.e. 'Gerak IKS SDC 2016' organized by the XYZ. The total of 250 questionnaires was distributed to the respondents during the 'Gerak IKS SDC 2016' entrepreneurial development program. Each respondent was given 30 minutes to answer the questionnaire. For the record, the participants were randomly selected during three Gerak IKS SDC 2016 programs organised in three major towns in the State. It was done by the permission of XYZ and participants were informed by the organizer before the session started. Out of 250 questionnaires distributed, only 149 questionnaires were returned with 121 usable in this study. All usable responses were further analysed using Statistical Package for Social Science (SPSS). Table 1 below shows the profile of respondents.

TABLE 1. Profile of respondents

\begin{tabular}{lll}
\hline \hline Demography & Description & Frequency \\
\hline Gender & Male & $64 \%$ \\
Age & Female & $47 \%$ \\
& $18-25$ Years & $12 \%$ \\
& $26-35$ years & $24 \%$ \\
Marital Status & $36-45$ years & $49 \%$ \\
& $45-55$ years & $15 \%$ \\
& Single & $21 \%$ \\
& Married & $65 \%$ \\
Level of Education & Divorced & $12 \%$ \\
& Spouse Deceased & $2 \%$ \\
Annual Income & Completed up to SPM & $42 \%$ \\
& Completed up to STPM & $23 \%$ \\
Ethnic Group & At least Diploma Level & $35 \%$ \\
& Less than RM20,000 & $78 \%$ \\
& At least RM20,000 & $22 \%$ \\
& Malay & $29 \%$ \\
& Bajau & $13 \%$ \\
& Suluk & $9 \%$ \\
& Kadazan/Dusun & $33 \%$ \\
& Chinese & $12 \%$ \\
\hline \hline
\end{tabular}

Majority of the respondents are Male (64\%). Most of the respondents are 36-45 years (49\%) and most of them are married (65\%). In term of level of education, majority of respondents have completed up to SPM (42\%) and $23 \%$ respondents have completed up to STPM level. The respondents having Diploma qualification is the second highest group (35\%). In addition, majority (78\%) of respondents fall under the category of low income earner, i.e. less than RM20,000 (78\%). The respondents can be categorised into a number of ethnic groups which are Kadazan/Dusun (33\%), Malay (29\%), Bajau (13\%), Chinese (12\%), Suluk (9\%) and others (4\%).

\section{RESULTS}

The questionnaire is structured into 16 items that are designed to capture the level of financial literacy of respondents where, each correct answer by the respondent will be counted as score of one (Lim et al., 2012). The possible score range for financial literacy of respondents is therefore 0 (being the lowest) to 16 (being the highest). Table 2 shows the descriptive statistics that elaborate the result of the literacy survey. 
TABLE 2 . Literacy score of respondents

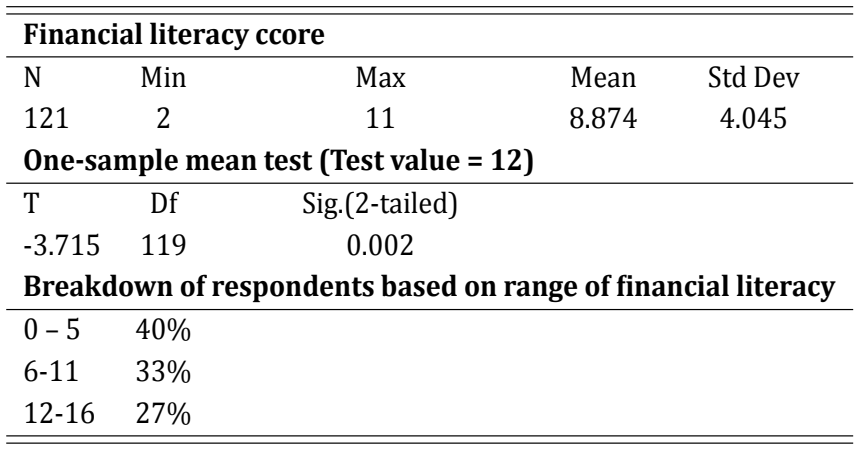

The mean value for the financial literacy is 8.87 , which is far below the midpoint of the possible score which is 12 . In addition, the $p$-value of one-sample mean test of 0.002 concludes that financial literacy of respondents is significantly lower than the test value. Table 2 also reveals that majority of respondents i.e. $40 \%$ only managed to answer correctly between 0 and 5 questions. This is followed by $33 \%$ of respondents who answered 6-11 questions correctly and 27\% of them managed to answer 12-16 questions correctly. Independent sample t-test is employed to investigate the relationship between the level of financial literacy and group comparisons of respondents. Table 3 below represents the results.

TABLE 3 . Results of independent sample tests

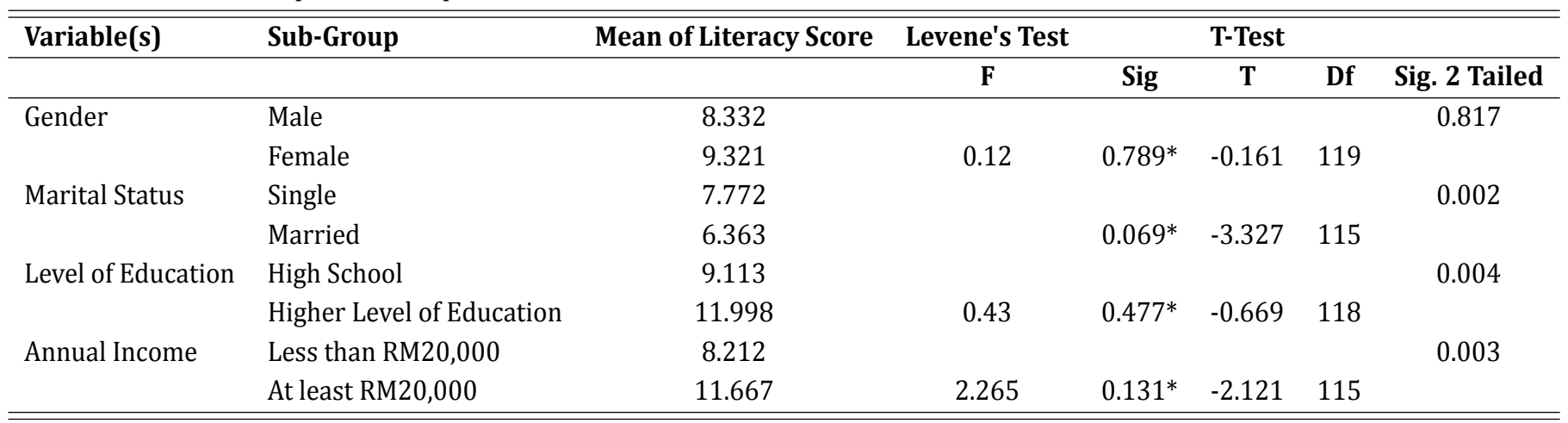

Since the $p$-values for all five Levene's tests are above 0.05 , the interpretation of the independent sample t-tests are on the assumption that variances are equal. From the table 3 , it is shown that the group of female respondents is having a better literacy level (mean of 9.321) as compared to male respondents (mean of 8.332). This is consistent with the findings of previous studies which prove that females are better than males in term of financial management (Sang, Osman, Zatul Karamah, Jamal \& Mohidin, 2012; Njaramba, Chigeza \& Whitehouse, 2015). Single respondents are found to be more literate financially than married respondents. Their mean values are 7.772 and 6.363 respectively.

As expected, the respondents with higher level of education who hold at least Diploma level of academic qualification with the mean value of 11.998 are found to be more literate financially than those who just completed up to the high school level (completed up to STPM) with the mean of 9.113. Finally, respondents with at least annual income of RM20,000 seemed to be able to manage their income wisely than those with annual income less than RM20,000. The mean values are 11.667 and 8.212 respectively. Although female is better than male in terms of financial manageISSN: 2414-309X ment, but statistically this difference is not significant. The $\mathrm{p}$-value between female and male is 0.817 . This implies that gender is not giving any implication to financial literacy. However, financial literacy gap exists among marital status, level of education and annual income. The p-value generated by the independent sample t-test between single and married, higher education level and high school and annual income of at least RM20,000 and less than RM20,000 are statistically found at $0.002,0.004$ and 0.003 respectively. These indicate that those variables do give implication to financial literacy (Lim et al., 2012; Mabhanda, 2015).

\section{DISCUSSION AND CONCLUSION}

The present study aims to analyse the level of financial literacy among the candidates of SMEs' entrepreneur programs. The finding shows that there is a significant relationship between the candidates and level of financial literacy. Whereby, it indicates that there is low level financial literacy among the candidates. This is consistent with previous studies which also found low level of financial literacy among entrepreneurs (Plakaloviæ, 2015; Abubakar, 2015; Fatoki, 2014).

In addition, the result discloses that majority of the reTAF 1 Publishing 
spondents (40\%) are having serious issues with their financial knowledge as they only managed to answer between 0 and 5 financial literacy question items correctly. Indeed, as proposed by Lonnex (2014), financial literacy education should start as early as possible to equip entrepreneurs with the ability to make sound financial decisions and pursue business opportunities that make sense. The findings of this research are insightful to many parties and stakeholders, those are directly or indirectly involved in designing and implementing entrepreneurial program in Malaysia, especially those organised by implementing agencies in public sector. Few suggestions could be taken into consideration.

First, the level of financial literacy among SMEs' players, particularly those selected to be nurtured as new entrepreneurs is still alarming. As such their ability to manage financial matters of their enterprise is questionable, so is the survival of their business (Chittithaworn, Islam, Keawchana \& Yusuf, 2011; Musa, 2016). Second, the component of financial management education must be considered seriously in designing entrepreneurial program so as to equip selected participants with necessary financial management skills. Third, a systematic monitoring program and tracking system should be developed by the implementing agencies so that the progression of financial literacy among the participants can be measured as to enable the agencies to provide necessary assistance sustainably. Fourth, the element of financial literacy must be employed as one of the criteria to select potential participants (Islam \& MuktadirAl-Mukit, 2013; Kurniawati \& MeilianaIntani, 2016). Finally this study suggests that the spectrum of this study should be enlarged to cover bigger scope of population and more variety of respondents' demographical background.

\section{REFERENCES}

Abubakar, H.A. 2015. Entrepreneurship development and financial literacy in Africa. World Journal of Entrepreneurship, Management \& Sustainable Development, 11(4): 281-294. D0I: 10.1108/WJEMSD-04-2015-0020

Adomako, S., \& Danso, A. 2014. Financial literacy and firm performance: The moderating role of financial capital availability and resource flexibility. International Journal of Management \& Organizational Studies , 3(4): 1-15.

Ankunda, O.D. 2010. Financial literacy key for SME growth. URL: goo.gl/GRK37q. Last accessed on 4 December 2016.

Bayrakdaroğlu, A., \& Şan, F.B. 2014. Financial literacy training as a strategic management tool among small medium sized businesses operating in Turkey. Procedia-Social \& Behavioral Sciences, 150: 148-155.

DOI: $10.1016 /$ j.sbspro.2014.09.019

Chamwada, V. K. 2015. The effect of financial literacy on financial performance of small and micro enterprises in Kibera slums. URL: goo.gl/ouUtMF. Last accessed on 26 December 2016.

Cherugong, P. 2015. The effect of financial literacy on performance of small and medium enterprises in Trans Nzoia county. Unpublished doctoral dissertation, University of Nairobi, Nairobi, KE.

Chittithaworn, C., Islam, M.A., Keawchana, T., \& Yu suf, D.H.M. 2011. Factors affecting business success of small \& medium enterprises (SMEs) in Thailand. Asian Social Science, 7(5): 180-185.

Fatoki, O. 2014. The financial literacy of micro entrepreneurs in South Africa. Journal of Social Science, 40(2): 151-158.

Fernandes, T. I.M. 2015. Financial literacy levels of small businesses owners and it correlation with firms' operating performance. URL: goo.gl/uCzVSy. Last accessed on 29 November 2016.

Gunto, M. \& Alias, M. 2013. SMEs development in Malaysia: Lessons for Libya. Prosiding Perkem, 8(3): 1521- 153.

Halabi, A.K., Barrett, R., \& Dyt, R. 2010. Understanding financial information used to assess small firm performance: An Australian qualitative study. Qualitative Research in Accounting \& Management, 7(2): 163-179.

DOI: $10.1108 / 11766091011050840$

Hoe, C.H. 2010. Financial management practices: An in-depth study among the CEOs of small and medium enterprises (SMEs). International Review of Business Research Papers, 6(6): 13-35.

Hoq, M.Z., Che Ha, N., \& Said, S.M. 2009. SMEs in the Malaysian economy. International Journal of Marketing Studies, 1(2): 3-17. DOI: $10.5539 /$ ijms.v1n2p3

Islam, N., \& Muktadir-Al-Mukit, D. 2013. Factors determining the success of SMEs in Bangladesh. URL: goo.gl/UkYo o2. Last accessed on 26 March 2017.

Koe, W.L., Omar, R., \& Sa' ari, J.R. 2015. Factors Influencing propensity to sustainable entrepreneurship of SMEs in Malaysia.

Procedia-Social \& Behavioral Sciences, 172: 570-577. D0I: 10.1016/j.sbspro.2015.01.404

Kojo Oseifuah, E. 2010. Financial literacy and youth entrepreneurship in South Africa. African Journal of Economic \& 
Man- $\quad$ agement Studies, 1(2): 164-182. DOI: 10.1108/20400701011073473

Kotzé, L., \& Smit, A. 2008. Personal financial literacy and personal debt management: The potential relationship with new venture creation. The Southern African Journal of Entrepreneurship \& Small Business Management, 1(1): 35-50. DOI: $10.4102 /$ sajesbm.v1i1.11

Kurniawati, E.P., \& MeilianaIntani, A. 2016. Effect analysis of the use of accounting information, managerial performance and employee performance Towards SMEs. Journal of Administrative \& Business Studies, 2(3): 130-142.

Lennox, V. 2014. It's time to bridge the entrepreneur financial literacy gap. URL: goo.gl/9cKE1W. Last accessed on 4 December 2016.

Lim, T.S., Osman, Z., Zatul Karamah, A., Abd Jamal, A.A., \& Awang Mohidin, R. 2012. Financial literacy in the east coast of Sabah: A pilot results. URL: goo.gl/wEsZem. Last accessed on 26 December 2016.

Mabhanda, W. 2015. Lack of financial literacy exacerbates of SMEs' appalling state in Gweru city. Journal of Business Man- agement Science, 1 (12): 11-29.

Marcolin, S., \& Abraham, A. 2006. Financial literacy research: Current literature and future opportunities. Paper pre- $\quad$ sented at the 3rd International Conference on Contemporary Business, Adelaide, AU.

Marriott, N., \& Mellett, H. 1996. Health care managers' financial skills: Measurement, analysis and implications. Accounting Education, 5(1): 61-74. DOI: 10.1080/09639289600000006

Mazzarol, T. 2014. The importance of financial management to SMEs. URL: goo.gl/AP1q5X. Last accessed on 26 Decem- ber 2016.

Mgijima, B., \& Flowerday, S. 2012. Internet success for the small and medium hospitality enterprise: Influence of the owner or manager. African Journal of Business Management, 6(37): 10222-10228.

Mutegi, H.K., Njeru, P.W., \& Ongesa, N.T. 2015. Financial literacy and its impact on loan repayment by small and medium entrepreneurs: An analysis of the effect of book keeping skills from equity group foundation's financial literacy training program on entrepreneurs' loan repayment performance. International Journal of Economics Commerce \& Manage- ment, 3(3): 1-28.

Mutua, J.M. 2015. Effect of bookkeeping on the growth of small and medium enterprises in Chuka Town. European Journal of Business \& Social Sciences, 4(07): 102-112.

Musa, G. 2016. The role of accounting education towards the development of small and medium enterprises in Jigawa State. International Journal of Business \& Administrative Studies, 2(4): 96-102.

Njaramba, J., Chigeza, P. , \& Whitehouse, H. 2015. Financial literacy: The case of migrant African-Australian women en- trepreneurs in the Cairns region. Entrepreneurship \& Sustainability Issues, 3(2): 198-208.

DOI: $10.9770 /$ jesi.2015.3.2(7)

Njoroge, R.M. 2013. Relationship between financial literacy and entrepreneurial success in Nairobi County Kenya. URL: goo.gl/0o4wVS. Last accessed on 30 November 2016.

Nunoo, J., \& Andoh, F. K. 2012. Sustaining small and medium enterprises through financial service utilization: Does financial literacy matter? Paper presented at the Agricultural \& Applied Economics Association's 2012 AAEA Annual Meeting, Seattle, WA.

Organisation for Economic Cooperation and Development. 2011. Improving financial education efficiency: OECD-bank of Italy symposium on financial literacy. URL: goo.gl/ijbL64. Last accessed on 25 December 2016.

Olatunji, O.S. 2015. The impact of information communication technology on small and medium scale enterprises pro- ductivity in Nigeria. URL: goo.gl/F85izj. Last accessed on 24 December 2016.

Plakaloviæ, N. 2015. Financial literacy of SMEs managers managing intellectual capital and innovation for sustainable and inclusive society: Managing intellectual capital and innovation. Paper presented at the International Conference MakeLearn and TIIM Joint, Bari, IT.

Salikin, N., Ab Wahab, N., \& Muhammad, I. 2014. Strengths and weaknesses among Malaysian SMEs: Financial management perspectives. Procedia-Social \& Behavioral Sciences, 129, 334-340. D0I: 10.1016/j.sbspro.2014.03.685

Sang, L.T., Osman, Z., Zatul Karamah, A.B.U., Jamal, A.A.A., \& Mohidin, R.A. 2012. Financial literacy in the east coast of Sabah: A pilot results. Paper presented at the Proceedings of Internatioanal Borneo Business Conference, Universiti 
Malaysia Sabah, Sabah, MA.

Shafique, M.R., Rizwan, M., Jahangir, M.M., Mansoor, A., Akram, S., \& Hussain, A. 2013. Determinants of entrepreneurial suc- $\quad$ cess/failure from SMEs perspective. Journal of Business \& Management, 15(2): 83-92.

Tuyisenge, H.J., Mugambi, F. \& Kemirembe, O.M. 2015. The Role of financial literacy on loan repayment among small and medium entrepreneurs in Rwanda case study: Urwego opportunity bank. International Journal of Small Business \& Entrepreneurship Research, 3(5): 33-36.

Wang, Y. 2016. What are the biggest obstacles to growth of SMEs in developing countries? An empirical evidence from an enterprise survey. Borsa Istanbul Review, 16(3): 167-176. DOI: 10.1016/j.bir. 2016.06.001

Wise, S. 2013. The impact of financial literacy on new venture survival. International Journal of Business \& Manage- ment, 8(23): 30-39. DOI: 10.5539/ijbm.v8n23p30

World Bank. 2012. World development indicators 2012. Washington, DC, WA: World Bank Publications.

— This article does not have any appendix. — 